\title{
First molar extractions related to molar-incisor hypomineralization (MIH) in a special need patient: case report
}

\author{
Extrações de primeiros molares relacionadas à hipomineralização molar-incisivo (HMI) em um \\ paciente com necessidades especiais: relato de caso clínico
}

Extracciones de primeros molares relacionadas con hipomineralización molar-incisivo (MIH) en un paciente con necesidades especiales: reporte de un caso

\begin{abstract}
Although most orthodontists avoid extractions, treating patients with biprotrusion traditionally involves removing teeth. In the current case report, a 15-year-old deaf patient had a Class II molar and canine relationships, $8 \mathrm{~mm}$ overjet and $3 \mathrm{~mm}$ overbite, $3 \mathrm{~mm}$ of a discrepancy between U/L midline, crowding in both arches $(3 \mathrm{~mm}$ in the upper and $7 \mathrm{~mm}$ in the lower). The first right upper molar (16) and the first right and left lower molars (36 and 46) were severely MIH affected. Extraction of the first four molars was proposed, since a large amount of space was required and three of the four molars were very compromised with severe MIH. Tooth 26 was extracted to maintain the symmetry of the arch and because the extraction of a premolar would not allow for alignment associated with class II correction of canines on the left side. During the closure of the extraction spaces, upper and lower third molars eruption was observed, in an appropriate position. Facial analysis shows us the coincidence of the upper midline with the face and good exposure of the incisors in the smile. There was considerable reduction of overjet and dental protrusion, enabling passive lip sealing. A perfect fit of the Class I superior teeth was not obtained since the patient considered that the treatment was already very good and did not want to collaborate with hygiene and the use of orthodontic appliances for more time.
\end{abstract}

Keywords: Tooth extraction; Dental enamel hypoplasia; Malocclusion.

\section{Resumo}

Embora a maioria dos ortodontistas evite extrações, o tratamento de pacientes com biprotrusão tradicionalmente envolve a remoção dos dentes. No relato de caso atual, uma paciente surda de 15 anos de idade tinha relação de molares e caninos de Classe II, sobressaliência de $8 \mathrm{~mm}$ e sobremordida de $3 \mathrm{~mm}, 3 \mathrm{~mm}$ de discrepância entre a linha média S/I, apinhamento em ambos os arcos (3 mm no superior e $7 \mathrm{~mm}$ no inferior). O primeiro molar superior direito (16) e os primeiros molares inferiores direito e esquerdo (36 e 46) foram gravemente afetados por HMI. A extração dos quatro primeiros molares foi proposta, uma vez que era necessário um grande espaço e três dos quatro molares estavam muito comprometidos com HMI grave. $\mathrm{O}$ dente 26 foi extraído para manter a simetria do arco e porque a extração de um pré- 
molar não permitiria o alinhamento associado à correção de classe II de caninos do lado esquerdo. Durante o fechamento dos espaços de extração, observou-se erupção dos terceiros molares superiores e inferiores, em posição adequada. A análise facial nos mostra a coincidência da linha média superior com a face e boa exposição dos incisivos no sorriso. Houve redução considerável do overjet e da protrusão dentária, permitindo o selamento labial passivo. Não foi obtido um encaixe perfeito dos dentes superiores de Classe I, pois o paciente considerou que o tratamento já era muito bom e não queria colaborar com a higiene e o uso de aparelhos ortodônticos por mais tempo.

Palavras-chave: Extração dentária; Hipoplasia do esmalte dentário; Má oclusão.

\section{Resumen}

Aunque la mayoría de los ortodoncistas evitan las extracciones, el tratamiento de los pacientes con biprotrusión implica tradicionalmente la extracción de dientes. En el presente caso clínico, un paciente sordo de 15 años tenía relaciones molares y caninas de clase II, resalte de $8 \mathrm{~mm}$ y sobremordida de $3 \mathrm{~mm}, 3 \mathrm{~mm}$ de discrepancia entre la línea media U / $\mathrm{L}$, apiñamiento en ambas arcadas ( $3 \mathrm{~mm}$ en la superior y $7 \mathrm{~mm}$ en la inferior). El primer molar superior derecho (16) y los primeros molares inferiores derecho e izquierdo (36 y 46) estaban gravemente afectados por MIH. Se propuso la extracción de los primeros cuatro molares, ya que se requería una gran cantidad de espacio y tres de los cuatro molares estaban muy comprometidos con MIH severo. El diente 26 se extrajo para mantener la simetría del arco y porque la extracción de un premolar no permitiría la alineación asociada con la corrección de clase II de los caninos del lado izquierdo. Durante el cierre de los espacios de extracción se observó erupción de los terceros molares superiores e inferiores, en una posición adecuada. El análisis facial nos muestra la coincidencia de la línea media superior con el rostro y buena exposición de los incisivos en la sonrisa. Hubo una reducción considerable del resalte y la protuberancia dentaria, lo que permitió el sellado pasivo de los labios. No se obtuvo un ajuste perfecto de los dientes superiores Clase I ya que el paciente consideró que el tratamiento ya era muy bueno y no quiso colaborar con la higiene y el uso de aparatos de ortodoncia por más tiempo.

Palabras clave: Extracción dental; Hiplopasia del esmalte dental; Maloclusión.

\section{Introduction}

Orthodontic planning for Class II Angle patients with biprotrusion traditionally involves dental extractions, especially when it is associated with dental crowding. Premolars are the most frequently chosen teeth. However, in light of the seriousness of the problem, there may not be sufficient space to correct the malocclusion and the choice must also consider the patient's age, the orthodontist's knowledge, and the patient's preferences.(Booij et al., 2021)

A less usual practice is the extraction of the first permanent molars. Extracting these elements is not the first choice, but when these teeth are compromised with extensive caries lesions or restorations, periodontal or endodontic problems, they may be chosen(Livas, Halazonetis, Booij, \& Katsaros, 2011; Stalpers, Booij, Bronkhorst, Kuijpers-Jagtman, \& Katsaros, 2007) and when the third molar is viable that will occupy the space left by the mesialization of the second tooth.(Baik et al., 2020) In addition to the adverse clinical conditions cited, there are those that result from structural defects, representing an option in the indication for extraction. Among them, it is important to mention Molar- incisor hypomineralization (MIH).

MIH is characterized by demarcated qualitative defects of enamel of systemic origin that affects one or more permanent first molars, with or without incisor involvement.(Weerheijm et al., 2003; Weerheijm, Jälevik, \& Alaluusua, 2001) Clinically, the affected enamel is porous and fragile, often leading to a rapid collapse in the eruption and exposure to masticatory forces.

The prevalence of MIH varies between 2.8-40.2\%.(Elfrink, Ghanim, Manton, \& Weerheijm, 2015; Jälevik, 2010) The etiological factors are still controversial(Crombie, Manton, \& Kilpatrick, 2009) with considerable evidence of association between diseases in early childhood (in particular, fever)(Silva, Scurrah, Craig, Manton, \& Kilpatrick, 2016) respiratory diseases(Kühnisch et al., 2014) and perinatal complications.(Weerheijm \& Mejàre, 2003) Currently, the genetic cause is related to disturbances in the enamel maturation stages.(Vieira \& Kup, 2016)

The color and opacity of the enamel can be used as a guide to the severity of the condition, since yellow and brown opacities have a worse prognosis when compared to lighter ones.(Cabral, Nyvad, Soviero, Freitas, \& Leal, 2019) The quality of life is very negatively impacted, and they suffer numerous clinical problems such as exacerbated sensitivity including during brushing, resulting in poor oral hygiene.(Raposo, de Carvalho Rodrigues, Lia, \& Leal, 2019) Untreated teeth evolve with pulp 
involvement and, consequently, with early loss.(Ghanim et al., 2017) In addition, the treatment has a very large financial impact on the patient and society, since the affected teeth easily develop caries relapses.(Elfrink et al., 2015)

The objective of this case report is to present and discuss a treatment of a special need patient with an Angle Class II, biprotrusion with severe crowding and MIH molars.

\section{Metodology}

This article is a study based on a descriptive and qualitative clinical case report, whose treatment option was based on, and discussed, in accordance with the orthodontic literature published in recent years, indexed in the PubMed, Google Scholar, Scielo and EBSCO.

\section{Case Report}

A 15-year, 11-month-old female patient reported dissatisfaction with her smile aesthetics due to the excessive protrusion of the incisors and exacerbated sensitivity in the first molars affected by the MIH. These molars had already been restored numerous times, but without success in terms of aesthetics, low longevity of restorations with successive breaks and hypersensitivity. The gestational history included an absence of prenatal care up to 20 weeks and presence of chronic maternal anemia with preterm birth (30 weeks). The patient presented hidden spina bifida at birth and bilateral deafness diagnosed at 8 months. In early childhood, she suffered from asthma, respiratory allergies, and repetitive episodes of tonsillitis. At the age of 7 she underwent cochlear implant surgery.

Facial analysis showed slight asymmetry, incompetence lip, convex face with bimaxillary protrusion, and dolichofacial type. Physical examination and model analysis found complete permanent dentition, crowding in both arches ( $3 \mathrm{~mm}$ in the upper and $7 \mathrm{~mm}$ in the lower), Class II molar and canine relationships, $8 \mathrm{~mm}$ overjet and $3 \mathrm{~mm}$ overbite; and $3 \mathrm{~mm}$ of a discrepancy between U/L midline (Figure 1-2).

Figure 1: Pretreatment extraoral and intraoral photographs.
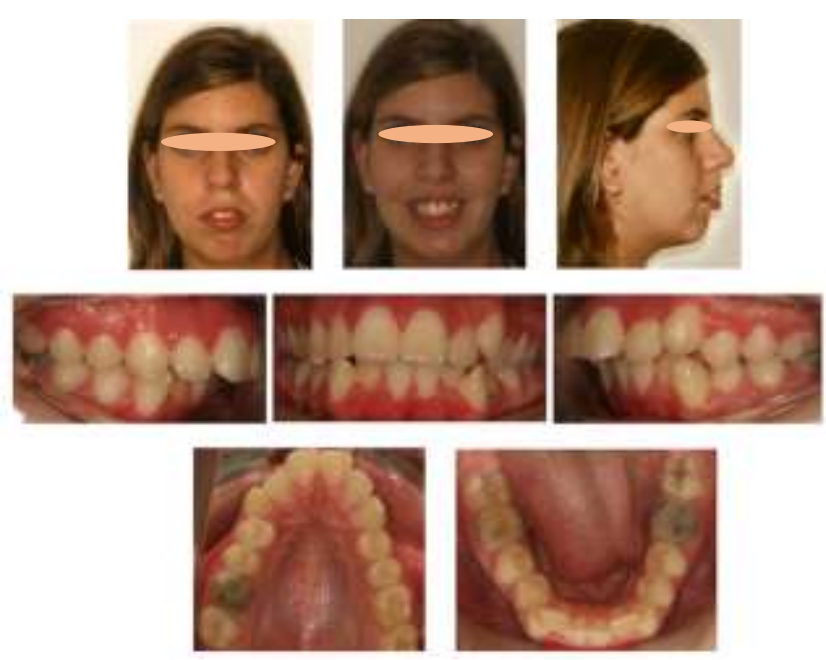

Source: Authors. 
Figure 2: Pretreatment dental casts.

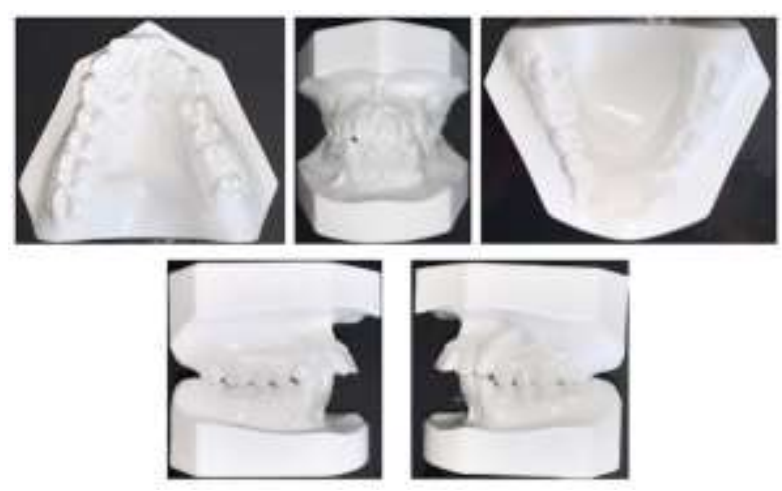

Source: Authors.

The first right upper molar (16) and the first right and left lower molars (36 and 46) were severely MIH affected. The crowns of the central incisors (11 and 21) and the cusps of the upper canines (13 and 23) showed demarcated opacities (slightly affected). These characteristics are consistent with the diagnosis of molar-incisor hypomineralization (MIH).

A panoramic radiograph suggested extensive atypical restorations in the crowns of teeth 16, 36 and 46, as well as the presence of good sized third molars with a favorable eruption axis. The patient is categorized in skeletal class II due to mandibular deficiency and the inclination of the lower incisors in relation to the vestibular being the clinical sign of compensation for this skeletal deficiency. The Teleradiograph showed marked protrusion of upper and lower incisors (Figure 3).

Figure 3: Pretreatment lateral cephalometric radiograph, cephalometric tracing and panoramic radiograph.
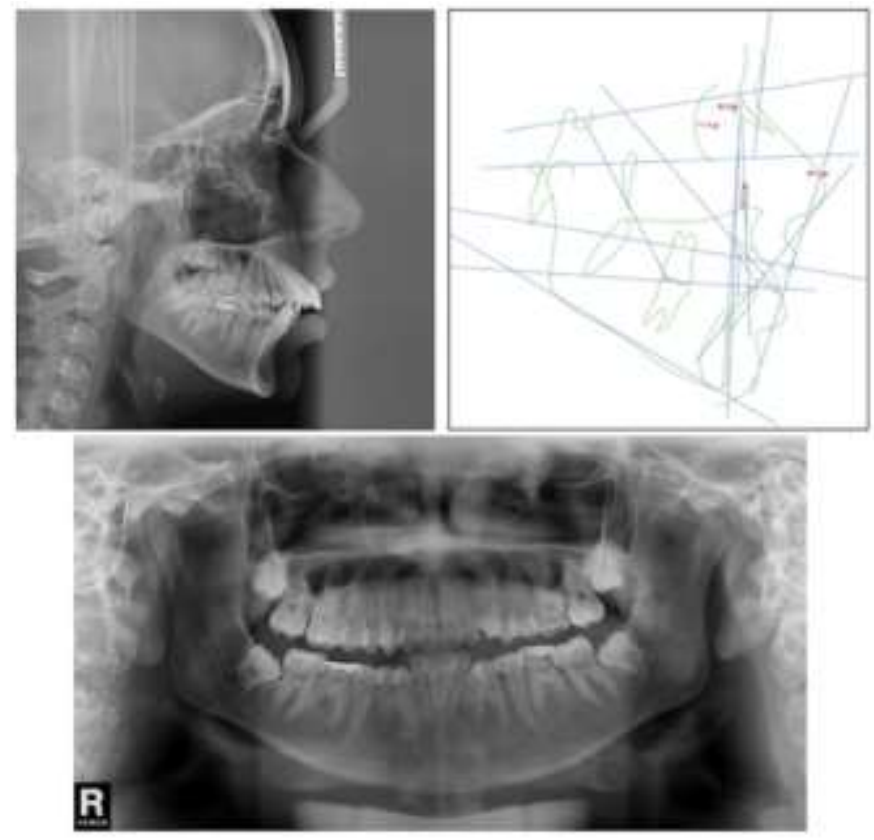

Source: Authors

Despite the cochlear implants, communication during orthodontic treatment between the patient and the orthodontist was challenging. Communication was achieved by her mother who used sign language or a conversation app on a smartphone. The use of messages via apps is related to the success of orthodontic treatment.(Leone, de Souza-Constantino, Conti, Filho, \& de Almeida-Pedrin, 2019) 
The objective of the orthodontic treatment was to align the teeth and decrease protrusion to allow passive lip sealing. Extraction of the first four molars was proposed, since a large amount of space was required and three of the four molars were very compromised with severe MIH. Tooth 26 was extracted to maintain the symmetry of the arch and because the extraction of a premolar would not allow the space needed. In addition, the option to extract the first premolar would still require extraction of the third molars due to the impossibility of erupting it due to lack of space.

The upper and lower 1-5 were bonded with MBT brackets and the second molars were banded. After extraction of the first molars, miniscrew implants were installed in the mesial of the second maxillary molars to retract the premolars and canines. In the lower arch, a Lingual Nance Arch (LNA) was installed. Alignment was performed by nickel-titanium wires up to the 0.019 "X 0.025 " steel arches and the LNA, after the retractions of the premolars and canines, were replaced by bonded tubes.

During the closure of the extraction spaces, upper and lower third molars eruption was observed, in an appropriate position, according to the intermediate panoramic radiograph, and then included in the treatment. This radiograph also showed mild root resorption in the upper and lower anterior teeth, consistent with the biological cost of the large orthodontic movement performed. The miniscrew implant inserted in the mesial of tooth 27 was maintained to assist in finalizing dental positioning.

For the final correction of the lower midline and to correct the class II on the left side, class II elastics on the left and midline were used. The chosen containment protocol was the 3X3 fixed retainer in the lower arch and the aligner type retainer for the maxilla, with night use.

The correction of crowding and bilateral class II was observed, in addition to the aesthetic gain and absence of pain after the extraction of the molars with severe MIH, although the protrusion of the lower incisors was maintained, due to their skeletal pattern.

Facial analysis shows us the coincidence of the upper midline with the face and good exposure of the incisors in the smile. There was considerable reduction of overjet and dental protrusion, enabling passive lip sealing. A perfect fit of the Class I superior teeth was not obtained since the patient considered that the treatment was already very good and did not want to collaborate with hygiene and the use of orthodontic appliances for more time (Figure 4-5), (Table 1).

Table 1: Pretreatment and Posttreatment skeletal and dental measurements.

\begin{tabular}{|c|c|c|c|}
\hline Measurement & Norm & Pretreatment & Posttreatment \\
\hline SNA, $^{\circ}$ & $82^{\circ}$ & $87^{\circ}$ & $85^{\circ}$ \\
\hline $\mathrm{SNB}^{\circ}$ & $80^{\circ}$ & $79^{\circ}$ & $79^{\circ}$ \\
\hline $\mathrm{ANB}^{\circ}$ & $2^{\circ}$ & $8^{\circ}$ & $6^{\circ}$ \\
\hline N-A.Pog, ${ }^{\circ}$ & $0^{\circ}$ & $8^{\circ}$ & $8^{\circ}$ \\
\hline Maxillary skeletal (A-N Perp), mm & $0,4 \mathrm{~mm}$ & $8 \mathrm{~mm}$ & $12 \mathrm{~mm}$ \\
\hline $\mathrm{Co}-\mathrm{A}, \mathrm{mm}$ & $93 \mathrm{~mm}$ & $83 \mathrm{~mm}$ & $85 \mathrm{~mm}$ \\
\hline Mandibular skeletal (Pg-N Perp) mm & $-1,8 \mathrm{~mm}$ & $9 \mathrm{~mm}$ & $8 \mathrm{~mm}$ \\
\hline $\mathrm{Co}-\mathrm{Gn}, \mathrm{mm}$ & $121 \mathrm{~mm}$ & $113 \mathrm{~mm}$ & $118 \mathrm{~mm}$ \\
\hline SNGGoGn, ${ }^{\circ}$ & $32^{\circ}$ & $39^{\circ}$ & $39^{\circ}$ \\
\hline FMA (MP-FH) & $25^{\circ}$ & $32^{\circ}$ & $33^{\circ}$ \\
\hline $1.1\left(^{\circ}\right)$ & $131^{\circ}$ & $100^{\circ}$ & $120^{\circ}$ \\
\hline 1.NA $\left({ }^{\circ}\right)$ & $22^{\circ}$ & $30^{\circ}$ & $20^{\circ}$ \\
\hline 1-NA (mm) & $4 \mathrm{~mm}$ & $8 \mathrm{~mm}$ & $4 \mathrm{~mm}$ \\
\hline $1 . \mathrm{NB}\left({ }^{\circ}\right)$ & $25^{\circ}$ & $35^{\circ}$ & $35^{\circ}$ \\
\hline $1-\mathrm{NB}(\mathrm{mm})$ & $4 \mathrm{~mm}$ & $11 \mathrm{~mm}$ & $9 \mathrm{~mm}$ \\
\hline $\operatorname{IMPA}\left({ }^{\circ}\right)$ & $87^{\circ}$ & $99^{\circ}$ & $98^{\circ}$ \\
\hline
\end{tabular}

Source: Authors. 
Figure 4: Posttreatments extraoral and intraoral photographs.

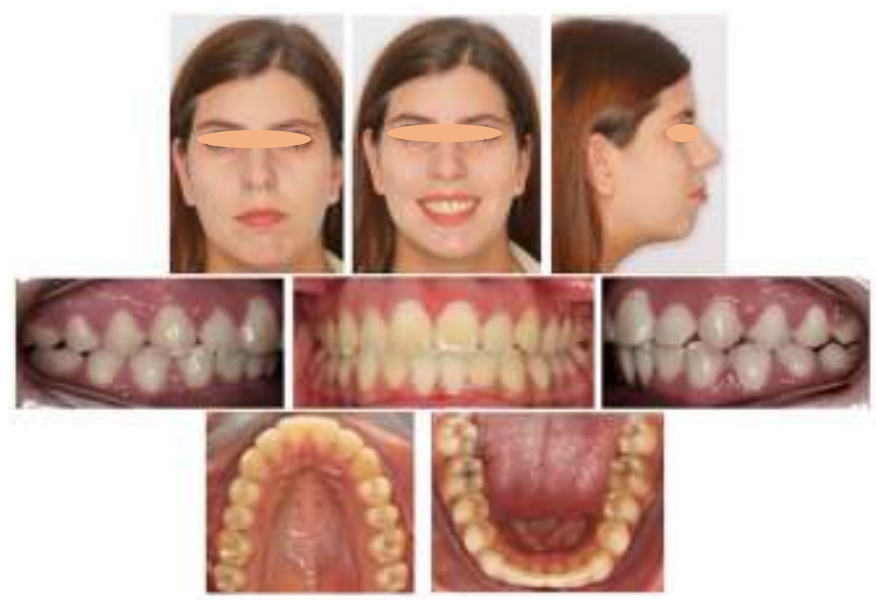

Source: Authors.

Figure 5: Posttreatment dental casts.

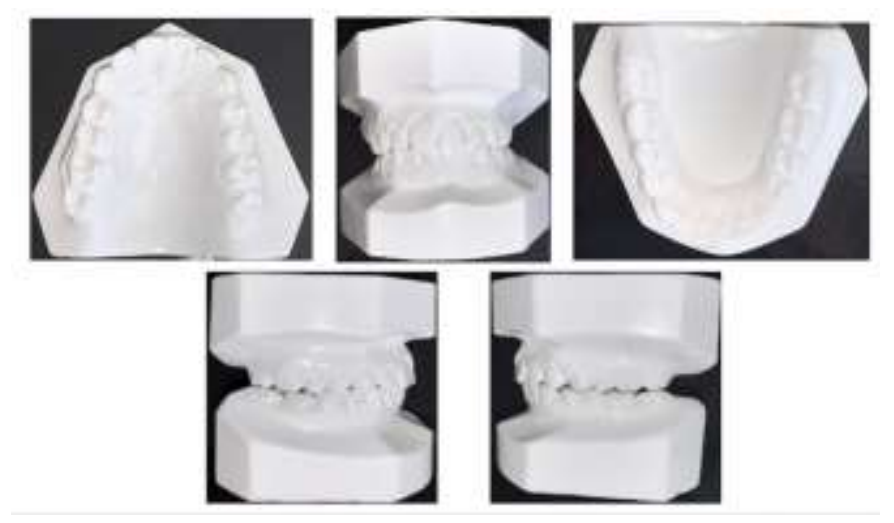

Source: Authors.

The completion, despite its limitations, proved to be excellent from the point of view of the patient and her parents. The patient reported improvement in her quality of life, since she no longer presented hypersensitivity, a condition that accompanied her since childhood. For the parents, eliminating the need for restorative retreatments was also a motive for satisfaction. 
Figure 6: Posttreatment lateral cephalometric radiograph, cephalometric tracing and panoramic radiograph.

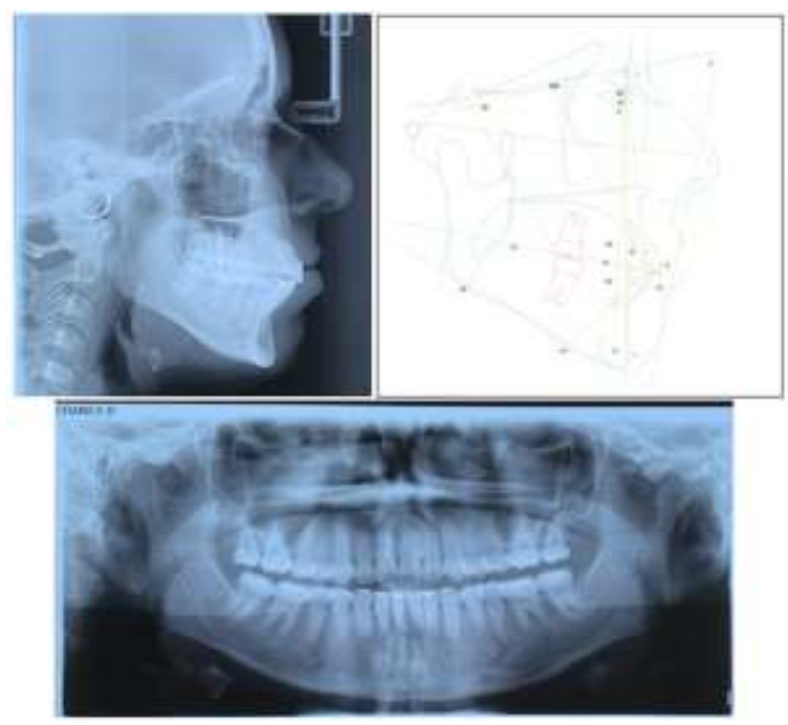

Source: Authors.

The overlap of cephalometric tracings revealed a reduction of the incisors' angulation, lip sealing and mesialization of the second superior and inferior molars, which allowed for the passive eruption of the third molars (Figure 6). The post-treatment cephalometric analysis (Table 1) showed retro inclination of the superior and inferior incisors, reduced angulation of the interincisors. These changes can be seen in the cephalometric superimposition (Figure 7).

Figure 7: Superimposition of pretreatment and posttreatment cephalometric radiographs.

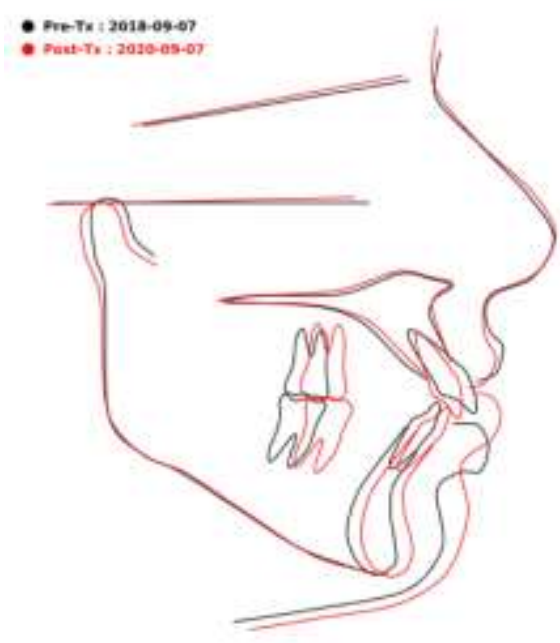

Source: Authors.

\section{Discussion}

Tooth extraction is indicated when there is generalized malocclusion, by the patient's age, and by the status of the neighboring teeth. Dentists need to consider the specific condition of each tooth, and the patient's needs and expectations when deciding how to administer the MIH. Extracting molars with severe enamel defects promotes good or acceptable results in most patients and, ultimately, favors the eruption of the third molar.(Bayram, Ozer, \& Arici, 2009; Cobourne, Williams, \& Harrison, 2014; Livas et al., 2011) Therefore, comprehensive clinical and radiographic examinations evaluating endodontic and 
periodontal pathologies, dental anatomy and dental position are essential in selecting teeth for extractions to improves the patient's overall oral health in the long run.(Chung, Choo, Lee, \& Kim, 2011)

Teeth affected by MIH have alterations in the enamel structure which can compromise their permanence in the oral cavity with losses related to aesthetics, function and quality of life, resulting in restorative treatments with a high financial cost.(Brusevold, Kleivene, Grimsøen, \& Skaare, 2021; Cobourne et al., 2014; Elhennawy, Jost-Brinkmann, Manton, Paris, \& Schwendicke, 2017; Ghanim et al., 2017) As a result, the extraction of the first permanent molars severely affected by MIH is indicated, preferably between 8-10 years of age.(Ghanim et al., 2017; Jälevik, 2010; Jälevik \& Möller, 2007) This would be the ideal age for extractions(Jälevik, 2010; Jälevik \& Möller, 2007) since, after extraction of the first molars prior to the eruption of the second molars, there is a spontaneous favorable development of the dentition, and eruption of the third molars.(Baik et al., 2020; Jälevik \& Möller, 2007) However, Baik and Cols(Baik et al., 2020) demonstrated that third molars at an advanced Nolla stage at the moment of mesialization of the second molars present higher eruption speed and greater spontaneous mesialization. In contrast, Brusevold et al consider that age is not the decisive factor in indicating or not the need for orthodontic treatment. However, in relation to the complete closure of spaces spontaneously, younger children showed better results. When comparing the arches, extraction of upper teeth was followed by spontaneous closure in all patients, while in the mandible, this occurred in only 51.6\%.(Brusevold et al., 2021) This patient underwent late extractions at 16 years of age and, therefore, had complete permanent dentition. The option for first molar extraction is only present in 3\% of orthodontic treatments with extractions(Janson, Maria, \& Bombonatti, 2014) and, in patients with MIH, extractions are performed at around 8 years of age(Jälevik \& Möller, 2007). These factors made the treatment of this patient challenging.

Patients with special needs are a reality in the dental office. There is a prevalence of $1.1 \%$ of the Brazilian population with hearing loss(IBGE), and about $0.4 \%$ of babies are already born with this disability. In Brazil, there is a lack of rehabilitation assistance for the hearing impaired since the detection of sound by means of cochlear implants does not guarantee the development of oral language.(Morettin et al., 2013) Communication difficulties with patients who cannot hear can be reduced using conversation apps, as was the case with this patient. The use of apps is recommended on orthodontic literature, both for communication and to encourage the use of elastics and oral hygiene.(Leone et al., 2019)

For the reasons cited above, a series of difficulties and challenges are associated with these types of orthodontic mechanics. The use of skeletal anchorage(Chung et al., 2011) minimizes most of the side effects of retraction of the anterior teeth and the closure of the remaining space.(Janson et al., 2014) This increase in treatment time, with its greater financial demand, can be offset by eliminating the repetitive restorative cycle that teeth with severe MIH are subjected to, with their high aggregate financial cost(Elhennawy et al., 2017), since $85 \%$ of molars in this condition need to be restored. These restorations last, on average, 5.2 years, and, in general, $48 \%$ of them are considered unacceptable.(Elhennawy et al., 2017) In the present case, as there was a large crowding associated with biprotrusion, the possibility of extracting four first premolars were discussed with those parents, to conclude the treatment with greater orthodontic rigor.(Cobourne et al., 2014) However, they did not accept the option of further extractions since the main complaints were already addressed.

With this patient, the correction of crowding and bilateral class II was observed, in addition to the aesthetic gain and absence of pain after the extraction of the molars with severe MIH, although the protrusion of the lower incisors was maintained, due to their skeletal pattern. The treatment improved her quality of life, both by eliminating the sensitivity associated with MIH(Raposo et al., 2019) and by reducing dental protrusion and bullying complaints.(Al-Omari et al., 2014)

In general, children with $\mathrm{MIH}$ are associated with a low quality of life, due to oral function limitations caused by chewing difficulties, pain or discomfort when drinking hot or cold foods, as well as aesthetic changes and caries disease. Malocclusions are also associated with decreased quality of life.(Dantas-Neta et al., 2016) The best treatment decisions must be made specifically for each tooth, considering the severity of its condition and the patient's expectation, which may be the 
application of sealant, direct / indirect restorations, or extraction. In the latter case, the patient's occlusion must be considered.(Cobourne et al., 2014; Ghanim et al., 2017; Steffen, Krämer, \& Bekes, 2017)

The extraction of first permanent molars severely affected by MIH can be a good treatment option, although it generates conflicting opinions between pediatric dentists and more conservative orthodontists. Preferably, extractions should be planned in collaboration with an orthodontist before the eruption of the second permanent molar. Studies show a favorable spontaneous development of permanent dentition after extraction of the first molar in most cases, although the best results occur when performed between 8 and 10 years of age(Teo, Ashley, \& Derrick, 2016) and when the third molars are present.(Jälevik, 2010; Jälevik \& Möller, 2007) For molars with severe MIH, extraction at the ideal age and, if necessary, orthodontic alignment can be cost-effective, especially when more than one molar is affected. When considering cost-effectiveness, this treatment must be the chosen one.(Elhennawy et al., 2017).

\section{Conclusion}

Orthodontic treatment may include the elimination of elements affected by MIH with good results, both from the aesthetic and from the biological point of view. As this is a case report, we suggest clinical research that investigates the impact of the treatment of HMI with extractions on the quality of life of patients, on the satisfaction with the facial profile after treatment and on the longevity of the results.

\section{Conflict of Interest Statement}

All authors declare that they have no conflict of interest.

\section{Ethics Statement}

This publication was authorized by the patient by signing the Informed Consent Form, allowing clinical practice and research to be based on ethical concepts. The manuscript content is original work and has not been published or submitted elsewhere. The submission is made on behalf of all authors. I confirm that I have read and understood the journal's guidelines on matters pertaining to the copyright, authorship as well as ethical and legal requirements of the study country.

\section{References}

Al-Omari, I. K., Al-Bitar, Z. B., Sonbol, H. N., Al-Ahmad, H. T., Cunningham, S. J., \& Al-Omiri, M. (2014). Impact of bullying due to dentofacial features on oral health-related quality of life. Am J Orthod Dentofacial Orthop, 146(6), 734-739. 10.1016/j.ajodo.2014.08.011

Baik, U. B., Kang, J. H., Lee, U. L., Vaid, N. R., Kim, Y. J., \& Lee, D. Y. (2020). Factors associated with spontaneous mesialization of impacted mandibular third molars after second molar protraction. Angle Orthod, 90(2), 181-186. 10.2319/050919-322.1

Bayram, M., Ozer, M., \& Arici, S. (2009). Effects of first molar extraction on third molar angulation and eruption space. Oral Surg Oral Med Oral Pathol Oral Radiol Endod, 107(2), e14-20. 10.1016/j.tripleo.2008.10.011

Booij, J. W., Kuijpers-Jagtman, A. M., Bronkhorst, E. M., Livas, C., Ren, Y., Kuijpers, M. A. R., \& Katsaros, C. (2021). Class II Division 1 malocclusion treatment with extraction of maxillary first molars: Evaluation of treatment and post-treatment changes by the PAR Index. Orthod Craniofac Res, 24(1), 102110. 10.1111 ocr. 12412

Brusevold, I. J., Kleivene, K., Grimsøen, B., \& Skaare, A. B. (2021). Extraction of first permanent molars severely affected by molar incisor hypomineralisation: a retrospective audit. Eur Arch Paediatr Dent. 10.1007/s40368-021-00647-w

Cabral, R. N., Nyvad, B., Soviero, V. L. V. M., Freitas, E., \& Leal, S. C. (2019). Reliability and validity of a new classification of MIH based on severity. Clin Oral Investig. 10.1007/s00784-019-02955-4

Chung, K. R., Choo, H., Lee, J. H., \& Kim, S. H. (2011). Atypical orthodontic extraction pattern managed by differential en-masse retraction against a temporary skeletal anchorage device in the treatment of bimaxillary protrusion. Am J Orthod Dentofacial Orthop, 140(3), 423-432. 10.1016/j.ajodo.2009.08.036

Cobourne, M. T., Williams, A., \& Harrison, M. (2014). National clinical guidelines for the extraction of first permanent molars in children. Br Dent J, 217(11), 643-648. 10.1038/sj.bdj.2014.1053 
Crombie, F., Manton, D., \& Kilpatrick, N. (2009). Aetiology of molar-incisor hypomineralization: a critical review. Int J Paediatr Dent, 19(2), 73-83. 10.1111/j.1365-263X.2008.00966.x

Dantas-Neta, N. B., Moura, L. F., Cruz, P. F., Moura, M. S., Paiva, S. M., Martins, C. C., \& Lima, M. D. (2016). Impact of molar-incisor hypomineralization on oral health-related quality of life in schoolchildren. Braz Oral Res, 30(1), e117. 10.1590/1807-3107BOR-2016.vol30.0117

Elfrink, M. E., Ghanim, A., Manton, D. J., \& Weerheijm, K. L. (2015). Standardised studies on Molar Incisor Hypomineralisation (MIH) and Hypomineralised Second Primary Molars (HSPM): a need. Eur Arch Paediatr Dent, 16(3), 247-255. 10.1007/s40368-015-0179-7

Elhennawy, K., Jost-Brinkmann, P. G., Manton, D. J., Paris, S., \& Schwendicke, F. (2017). Managing molars with severe molar-incisor hypomineralization: A cost-effectiveness analysis within German healthcare. J Dent, 63, 65-71. 10.1016/j.jdent.2017.05.020

Ghanim, A., Silva, M. J., Elfrink, M. E. C., Lygidakis, N. A., Mariño, R. J., Weerheijm, K. L., \& Manton, D. J. (2017). Molar incisor hypomineralisation (MIH) training manual for clinical field surveys and practice. Eur Arch Paediatr Dent, 18(4), 225-242. 10.1007/s40368-017-0293-9

IBGE. Pesquisa Nacional de Saúde. www.ibge.gov.br/PNS/20132013.

Janson, G., Maria, F. R., \& Bombonatti, R. (2014). Frequency evaluation of different extraction protocols in orthodontic treatment during 35 years. Prog Orthod, 15, 51. 10.1186/s40510-014-0051-z

Jälevik, B. (2010). Prevalence and Diagnosis of Molar-Incisor- Hypomineralisation (MIH): A systematic review. Eur Arch Paediatr Dent, 11(2), 59-64.

Jälevik, B., \& Möller, M. (2007). Evaluation of spontaneous space closure and development of permanent dentition after extraction of hypomineralized permanent first molars. Int J Paediatr Dent, 17(5), 328-335. 10.1111/j.1365-263X.2007.00849.x

Kühnisch, J., Mach, D., Thiering, E., Brockow, I., Hoffmann, U., Neumann, C., . . Group, G. P. S. (2014). Respiratory diseases are associated with molarincisor hypomineralizations. Swiss Dent J, 124(3), 286-293.

Leone, S. M. M., de Souza-Constantino, A. M., Conti, A. C. C. F., Filho, L. C., \& de Almeida-Pedrin, R. R. (2019). The influence of text messages on the cooperation of Class II patients regarding the use of intermaxillary elastics. Angle Orthod, 89(1), 111-116. 10.2319/011218-31.1

Livas, C., Halazonetis, D. J., Booij, J. W., \& Katsaros, C. (2011). Extraction of maxillary first molars improves second and third molar inclinations in Class II Division 1 malocclusion. Am J Orthod Dentofacial Orthop, 140(3), 377-382. 10.1016/j.ajodo.2010.06.026

Morettin, M., Cardoso, M. R., Delamura, A. M., Zabeu, J. S., Amantini, R. C., \& Bevilacqua, M. C. (2013). Use of the International Classification of Functioning, Disability and Health for monitoring patients using cochlear implants. Codas, 25(3), 216-223.

Raposo, F., de Carvalho Rodrigues, A. C., Lia, É., \& Leal, S. C. (2019). Prevalence of Hypersensitivity in Teeth Affected by Molar-Incisor Hypomineralization (MIH). Caries Res, 53(4), 424-430. 10.1159/000495848

Silva, M. J., Scurrah, K. J., Craig, J. M., Manton, D. J., \& Kilpatrick, N. (2016). Etiology of molar incisor hypomineralization - A systematic review. Community Dent Oral Epidemiol, 44(4), 342-353. 10.1111/cdoe.12229

Stalpers, M. J., Booij, J. W., Bronkhorst, E. M., Kuijpers-Jagtman, A. M., \& Katsaros, C. (2007). Extraction of maxillary first permanent molars in patients with Class II Division 1 malocclusion. Am J Orthod Dentofacial Orthop, 132(3), 316-323. 10.1016/j.ajodo.2006.01.034

Steffen, R., Krämer, N., \& Bekes, K. (2017). The Würzburg MIH concept: the MIH treatment need index (MIH TNI) : A new index to assess and plan treatment in patients with molar incisior hypomineralisation (MIH). Eur Arch Paediatr Dent, 18(5), 355-361. 10.1007/s40368-017-0301-0

Teo, T. K., Ashley, P. F., \& Derrick, D. (2016). Lower first permanent molars: developing better predictors of spontaneous space closure. Eur J Orthod, 38(1), 90-95. 10.1093/ejo/cjv029

Vieira, A. R., \& Kup, E. (2016). On the Etiology of Molar-Incisor Hypomineralization. Caries Res, 50(2), 166-169. 10.1159/000445128

Weerheijm, K. L., Duggal, M., Mejàre, I., Papagiannoulis, L., Koch, G., Martens, L. C., \& Hallonsten, A. L. (2003). Judgement criteria for molar incisor hypomineralisation (MIH) in epidemiologic studies: a summary of the European meeting on MIH held in Athens, 2003. Eur J Paediatr Dent, 4(3), 110-113.

Weerheijm, K. L., Jälevik, B., \& Alaluusua, S. (2001). Molar-incisor hypomineralisation. Caries Res, 35(5), 390-391. 10.1159/000047479

Weerheijm, K. L., \& Mejàre, I. (2003). Molar incisor hypomineralization: a questionnaire inventory of its occurrence in member countries of the European Academy of Paediatric Dentistry (EAPD). Int J Paediatr Dent, 13(6), 411-416. 